\title{
The capital structure of mature French SMEs and impact of the great recession: A dynamic panel data analysis (2002-2010)
}

\section{Philippe Adair ${ }^{1}$ (D), Mohamed Adaskou ${ }^{2}$}

1 University Paris-Est Créteil,

61 avenue du Général de Gaulle, 94000 Créteil, France

Professor, Faculty of Economics and Management

2 University Ibn Zohr,

Hya Dakhla, 8658 Agadir, Morocco

Associate Professor, Faculty of Law, Economics and Social Sciences

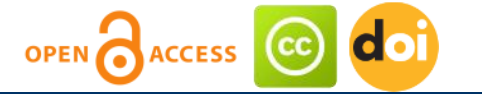

Article history:

Received: July 15, 2018

1st Revision: September

30, 2018

Accepted: October 26, 2018

\section{JEL classification: \\ L26 \\ E22 \\ G31}

DOI:

10.14254/jems.2018.3-2.5
Abstract: Two main theories of the capital structure are tested upon a balanced panel dataset of 2,370 French SMEs during nine years over the period 20032007 and the period 2008-2010, assessing the impact of the 2008 crisis accordingly. Trade-off theory is based on the optimisation of a target debt ratio, whereas pecking order theory argues that decisionmaking is sequential and that firms prefer internal funding to debt, due to asymmetry of information. Unlike other studies devoted to French SMEs, estimates come from a dynamic panel model (Generalised Method of Moments) applied to mature businesses. Profitability, guarantees upon which access to credit is granted, and trade credit confirm trade-off theory. Relationships between debt and the lagged debt ratio, growth opportunities, credit risk and control over ownership support the pecking order theory, which passes better the tests. Hence, no unified theory of the capital structure has yet emerged.

Keywords: balanced panel dataset, capital structure, Generalised Method of Moments, pecking order theory, French SMEs, trade-off theory, sustainable development. 


\section{Introduction}

Access to finance is currently a major challenge for Small and Medium Enterprises (SMEs).

The 2008 great recession was a double shock affecting SMEs: a fall in demand and tightening credit conditions (ECB, 2009). SMEs are more vulnerable in times of crisis: they cannot easily downsize because they are already small; their financial structure is fragile in as much as they depend on credit and their credit risk rating is weak.

This article investigates the financial structure of mature French SMEs and the effects of the 2008 great recession upon these by comparing the pre-crisis period and its aftermath. It is worth noting that among studies devoted to French SMEs in the past 20 years (See Table A1 in the Appendix), most covered prior shorter periods and small samples; neither did they use GMM estimation with the exception of Ziane (2004) nor did they address the impact of the 2008 crisis with the exception of Gurău et al (2018) that focus only upon micro-enterprises. So far, this article is the first one tackling the case for mature French SMEs.

Brealey, Myers \& Allen (2017) state that "how financial decisions are made" remains an unanswered question. However, standard corporate finance theory holds that its core concepts apply to the financing of all kinds of firms. It assumes the capital structure that maximise the firm value is a matter of choice depending upon a combination of various resources. Debt financing requires payback with cash flow commitments that are independent of the successful use of the loan. Equity financing is less risky as regards cash flow commitments, albeit it dilutes share ownership, control and earnings. The cost of equity is higher than the cost of debt, which is a deductible expense.

Search for evidence regarding the capital structure of firms (Rajan \& Zingales, 1995) and the existence of an optimal financial structure are ongoing research topics in corporate finance. Since the seminal work of Modigliani \& Miller $(1958,1963)$ on the capital structure of firms, several theories have developed to release the assumptions of perfect market and the absence of bankruptcy costs, agency costs or transaction costs.

Among these, two major theories emerged. On the one hand, Trade-Off Theory (TOT) holds that firms choose how to allocate their resources comparing the tax benefits of debt with the bankruptcy costs thereof, thus targeting an optimal debt ratio. On the other hand, Pecking Order Theory (POT) challenges the former theory, contending that firms rank sequentially their decision over funding sources: they avoid external financing if they have internal financing available and avoid new equity issuance whenever they can engage in new debt financing. Tests of POT have proved controversial. According to Shyam-Sunder \& Myers (1999), the test over a small sample (157 US firms) over the period 1971-1989 is positive, whereas Frank \& Goyal (2003) find that it fails for US small sized-firms whereof information asymmetry is important. Little attention has been paid to the fact that SMEs may not fit standard corporate finance theory, which deserves to be tested in this respect.

López-Gracia \&Sogorb-Mira (2008) point out that SMEs aim to achieve an optimal debt ratio, which is the best explanation for the capital structure of French SMEs (Dufour \& Molay, 2010). In contrast, Brounen, De Jong \&Koedijk (2004) hold that SMEs lack concern for such a ratio: their financial behaviour being distinct from that of large companies and one may look for a more relevant alternative theory.

In the absence of a theory specific to SMEs, research in finance attempted to adopt the teachings of these two theories to study debt behavior of these companies. The funding of SMEs faces various constraints such as the cost of credit, the level of own funds and dependence on customers and suppliers; these patterns deserves thorough analysis, particularly as regards the credit crunch and contraction in activity that occurred since 2008. SMEs often experience problems of asymmetric information, involving substantial information costs, which are typically addressed by POT. Nevertheless, these companies could also aim for a target debt ratio according to TOT.

\subsection{Research upon a controversial issue}

We address the following controversial issue: which of Trade-Off Theory (TOT) or Pecking Order Theory (POT) provides the best predictions as regards the borrowing behaviour of unlisted SMEs? We examine the main determinants of corporate leverage strategy (both short-term as well as medium and long-term debt) upon a sample of 2,370 French SMEs selected from the DIANE database over a nine-year period (2002-2010). It enables us to compare our outcomes with those of other French studies devoted to this issue since the 1990s, which mostly used non-dynamic panel data analysis upon smaller samples. Thus, our article provides an update and enlarges the prospect. 
Our paper is organised as follows: Section 2 sketches the core content related to TOT and POT as regards the debt ratio. Section 3 describes the key variables selected in order to test these assumptions. Section 4 presents the sample and descriptive statistics; it designs the theoretical model and econometric techniques. Section 5 examines the outcomes. Section 6 concludes.

\subsection{Literature review: Theories of the financial structure of SMEs}

\subsubsection{Trade-off Theory (TOT): Taxation, bankruptcy and agency costs}

Upon strong assumptions such as capital markets are perfect and there are neither tax or agency costs nor transaction costs, Modigliani \& Miller (1958) demonstrate that the financial structure is neutral vis-à-vis the value of the company. Later on, Modigliani \& Miller (1963) include taxation: the value of an indebted company is equal to that of a non-corporate debt, plus the present value of the tax savings from debt and less the present value of costs related to potential financial difficulties. Hence, because interest are deductible from taxable profits, firms have an incentive to use debt rather than equity. The value of a leveraged firm is higher in as much as the tax rebate benefits only the business itself, save personal income (Miller, 1977).

SMEs already enjoy a low tax rate that limits at some point any leverage policy conditional to a rebate on interest charges (Ang, 1991). According to Pettit \& Singer (1985), SMEs do not follow tax optimisation because they are less likely to be profitable.

The existence of bankruptcy costs (Stiglitz, 1969) involves a balance between the value of the firm and tax benefit; it theoretically drives to an optimal debt level when the marginal benefits associated with tax rebate are equal to the marginal costs associated with bankruptcy due to leverage.

Similarly, forsaking the hypothesis of no agency costs allows for the theoretical existence of an optimal capital structure. Agency theory (Jensen \& Meckling, 1976) assumes that there are conflicts of interest between the principal (shareholders) and the agent (business managers); hence, triggering agency costs that affect financing. Conflicts of interest between shareholders and creditors arise because the latter have priority over the former in case of bankruptcy. An optimal debt ratio is achieved when agency costs are minimum.

SMEs should tend to reduce debt in the event that bankruptcy costs are borne. SMEs face no or little agency costs between managers and shareholders, because they are often confused, unless the firm belongs to a group. However, agency conflicts between owners and lenders arise. According to Colot \& Michel (1996), the lender (principal) experiences difficulties in monitoring the decision of a small firm owner-manager (agent), mostly because transparency in information systems is missing, whereby generating agency costs (Cieply, 1997).

\subsubsection{Pecking Order Theory (POT) and asymmetry of information}

Myers \& Majluf (1984) developed Pecking Order Theory (POT) upon the asymmetry of information between internal stakeholders (owners and managers) and external providers of the firm. Business leaders adopt a financial policy, which aims at minimising the costs associated with asymmetric information, especially adverse selection, and prefer internal financing to external financing. Thus, decision making fits in the following sequence: self-financing, non-risky debt issuance, risky debt issuance and equity issuance as a last resort. Such behaviour eschews a fall in the prices of shares of the firm; it restricts the distribution of dividends in order to increase cash flow and reduces the cost of capital by limiting as much as possible access to loans. Thus, profitable firms enjoy more internal funds available.

Asymmetric information should drive the issue of debt over equity. Debt issuance signals the confidence of the board that an investment is profitable and that the current stock price is undervalued. Equity issuance signals a lack of confidence in the board that may feel the share price is overvalued. An issue of equity would therefore lead to a drop in share price. However, this may not apply to intangible assets.

Ang (1991) and Holmes \& Kent (1991) point out that POT applies to SMEs, save subcontracting SMEs or those belonging to a group (Kremp \& Phillippon, 2008). SMEs do not aim to achieve an optimal financial structure; they rank their preferences for internal financing over external financing, as well as debt relative to equity. They may wish to borrow when investment funding exceeds their internal cash flow, albeit they will face transaction costs for debt, which stand in between zero for cash flow and higher above for new shares issuance. The objective of SMEs managers is to maximise their own wealth, while securing control over decision-making vis-à-vis external actors. Hence, they will first choose internal funds for financing and if such funds prove 
unavailable, they prefer using debt rather than increasing their capital. POT is also supported with respect to assumptions regarding the age and profitability of SMEs: they use less debt as time goes by and when their life cycle leads from youth to maturity (Berger \& Udell, 1998).

Transaction costs economics, alongside with behavioral finance (Barberis \& Thaler, 2003) may also explain the financial behavior of SMEs. Williamson (1988) assumes opportunism and bounded rationality of agents, finding a close relationship between the determinants of financing choices and the nature of the asset to be funded. In the case of an intangible asset, the sequential preferences alleged by Myers \& Majluf (1984) would be reversed as follows: cash-flow in the first place, then equity and eventually debt. Moreover, routine behaviour is also challenging: Leary \& Roberts $(2010,2012)$ point out that companies issue shares when they should not do it and mimicry alone could explain up to $70 \%$ of corporate financing behaviour.

\section{Materials and Methods}

\subsection{Characteristics of French SMEs}

As in the case of other European countries (Daskalakis \& Psillaki, 2007), SMEs in France are the main source of employment ( $60 \%$ of jobs) and contribute to $55 \%$ of value added. SMEs constitute an unbalanced set of three categories: by January 2010, micro-enterprises (0-9 employees) account for $94.25 \%$ of all SMEs, hereas small enterprises (10-49 employees) and midsized enterprises (50-249 employees) account in respect for $4.80 \%$ and only $0.79 \%$ (OSEO, 2011).

Data may not always be consistent with the SMEs surveys upon small samples (one thousand firms as for France) the European Commission, together with Eurostat and the European Central Bank have designed since the early 2000s, especially regarding access to finance.

According to a survey upon French SMEs in 2010 (KPMG, 2012), trade credit remains the main source of financing corporate cash flow. Self-financing is the first source of investment funding (40-45\% of cases), followed by bank loans (34-38\% of cases). The average corporate debt ratio for SMEs is 88.6\%: the debt ratio is below 52\% for half of SMEs, whereas it is above $158 \%$ for a quarter of them. In 2009, the median weight of equity in the balance sheet of SMEs was $42 \%$. Three-quarters of SME managers declare being reluctant to open their capital to outside investors, in fear of losing their independence. Only 574 SMEs listed in 2010 access the financial market: out of 135,823 French small and midsize firms (excluding micro).

\subsection{Key variables and assumptions}

We identify capital structure by the debt ratio of the company $(D R)$, which is our dependent variable. We gauge it with the ratio of financial debt (short-term and medium-long-term) upon total assets, in line with Ziane (2004) as well as Dufour \& Molay (2010). The explanatory variables are the lagged debt ratio, age, profitability, growth opportunities, trade credit, guarantees, risk, and ownership (see Table 1). These key variables test the assumptions related to the debt ratio addressing the predictions of TOT vs. POT.

Thresholds of the three categories (micro, small and midsize enterprises) take care of the size of the company and there are specific estimates for each category of SMEs. We did not include variables related to the effects of taxation.

Lagged debt ratio from one period (DRt-1) is a determining variable for the current debt ratio and an increasing function of the size of the firm. This positive relationship can be explained by bankruptcy costs included in TOT: an inverse relationship is supposed to exist between size and the risk of bankruptcy; hence, the size of the firm can inform the creditors of a potential bankruptcy. Our first hypothesis (H1) assumes that debt in the past period influences the current debt; the relationship between size and the debt ratio being positive (TOT) or negative (POT).

As for age $(A G E)$, the older the firm, the larger its information record. TOT assumes the existence of a positive relationship between age and the debt ratio; the fact that mature firms have better reputation and more experience can reduce agency costs through a positive signal on the quality of potential investments. Conversely, assuming that the cash flow of SMEs is a positive function of age, mature firms have less recourse to leverage according to POT. Our second hypothesis (H2) states that mature firms do experience a higher debt ratio (TOT) vs. a lower one (POT). 


\begin{tabular}{|c|c|c|c|c|c|}
\hline $\begin{array}{l}\text { Theor } \\
\text { y }\end{array}$ & $\begin{array}{l}\text { Hypothes } \\
\text { is }\end{array}$ & Variables (reference) & Definition & $\begin{array}{l}\text { Cod } \\
\text { e }\end{array}$ & $\begin{array}{l}D \\
R\end{array}$ \\
\hline $\begin{array}{l}\text { TOT } \\
v s . \\
\text { POT }\end{array}$ & $H 1$ & Lagged debt ratio & Lagged variable (one year) & $\begin{array}{l}D R_{t-} \\
1\end{array}$ & + \\
\hline $\begin{array}{l}\text { TOT } \\
v s . \\
\text { POT }\end{array}$ & $H 2$ & Age & $\begin{array}{l}2002 \text { minus date of establishment. } \\
\text { Quantitative variable. }\end{array}$ & $A G E$ & $\begin{array}{l}+ \\
-\end{array}$ \\
\hline $\begin{array}{l}\text { TOT } \\
v s . \\
\text { POT }\end{array}$ & $H 3$ & Profitability & $\begin{array}{l}\text { Operating income / total assets. } \\
\text { Quantitative variable }\end{array}$ & $\begin{array}{l}P R O \\
F\end{array}$ & + \\
\hline $\begin{array}{l}\text { TOT } \\
v s . \\
\text { POT }\end{array}$ & $H 4$ & $\begin{array}{l}\text { Growth opportunities } \\
\text { (Dufour \& Molay, 2010) }\end{array}$ & Intangible assets / total assets. Quantitative variable & GO & - \\
\hline $\begin{array}{l}\text { TOT } \\
v s . \\
\text { POT }\end{array}$ & H5 & $\begin{array}{l}\text { Trade credit (customers - } \\
\text { suppliers) } \\
\text { (Dietsch \& Kremp, 1998) }\end{array}$ & $\begin{array}{l}\text { Credit to customers - accounts payable / total liabilities. } \\
\text { Quantitative variable }\end{array}$ & $T C$ & + \\
\hline $\begin{array}{l}\text { TOT } \\
v s . \\
\text { POT }\end{array}$ & H6 & $\begin{array}{l}\text { Guarantees (collateral) } \\
\text { (Bourdieu \& Colin-Sédillot, } \\
\text { 1993) }\end{array}$ & $\begin{array}{l}\text { Tangible fixed assets + inventories / total assets. } \\
\text { Quantitative variable }\end{array}$ & GAR & $\begin{array}{l}+ \\
-\end{array}$ \\
\hline $\begin{array}{l}\text { TOT } \\
v s . \\
\text { POT }\end{array}$ & $H 7$ & Credit risk & $\begin{array}{l}\text { Calculated score } \\
\text { Dummy variable }\end{array}$ & $R I S$ & $\begin{array}{l}+ \\
-\end{array}$ \\
\hline $\begin{array}{l}\text { TOT } \\
v s . \\
\text { POT }\end{array}$ & $H 8$ & $\begin{array}{l}\text { Ownership } \\
\text { (Chai \& Nguyen, 2011) }\end{array}$ & $\begin{array}{l}\text { Independent vs. group-owned firms (DIANE database) } \\
\text { Dummy variable }\end{array}$ & $\begin{array}{l}O W \\
N\end{array}$ & $\begin{array}{l}+ \\
-\end{array}$ \\
\hline
\end{tabular}

Source: Authors

Regarding the ratio of profitability $(P R O F)$, TOT assumes a positive relationship between profitability and the debt ratio. A profitable business may prefer debt because it maximises its value thanks to tax advantage; profitability sends the lender a signal as regards the financial health of the company that reduces information asymmetry. Conversely, according to POT, profitability exert a negative impact upon the debt ratio. Profitable companies will give priority to cash flow funding in order to secure their independence and to eschew exposure to information asymmetry. SMEs borrow only once they exhaust their ability to generate internal funds. In as much as profit determines cash flow, profitable firms are less leveraged. Our third hypothesis (H3) states that the relationship between profitability and the debt ratio is either positive (TOT) or negative (POT).

As for growth opportunities $(G O)$, agency theory holds that the relationship with the debt ratio should be negative: growth opportunities may induce moral hazard; firms are considered as more risky and fail convincing lenders to grant them credit; those with growth potential tend to have a low debt ratio (Myers, 1977). Conversely, according to POT, the relationship should be positive: the combination of growth potential and very limited access to financial markets drives SMEs to look for bank financing (Chittenden, Hall, and Hutchinson, 1996). Our fourth hypothesis (H4) states that the relationship between growth opportunities and the debt ratio should be negative (TOT) vs. positive (POT).

With trade credit (TC), the firm becomes a net lender or borrower depending on the sign in the balance of trade receivables and debts (Dietsch and Kremp, 1998). TOT holds that the ability of the firm to borrow from its trading partners may send to lenders a signal of its good payback capacity: trade credit exerts a positive effect as it eases granting bank credit thereof. In contrast, Petersen and Rajan (1994) argue that commercial debt is a substitute for financial debt when firms face credit rationing. For a large number of firms in the development stage of their lifecycle (including startups), trade credit is the main source of working capital as compared to bank loans (European Commission, 2003). According to POT, trade credit is less risky for SMEs: hence, the relationship with debt should be negative. Our fifth hypothesis (H5) states that trade credit affects the debt ratio, positively (TOT) vs. negatively (POT).

Guarantees $(G A R)$ or collateral is a major requirement from donors in the credit relationship (López-Gracia \& Sogorb-Mira, 2008); it reduces agency costs and drives commitment to longer term loans (Harris \& Raviv, 1990; Jensen \& Meckling, 1976). This requirement may also lessen the risk of moral hazard, as it is a means for self-selection of borrowers, deterring managers to under-invest and make discretionary levies (Myers, 1977; Besanko \& Thakor, 1987; Berger \& Udell, 1990). Titman \& Wessels (1988) argue that firms holding assets that may constitute a collateral are more leveraged. Our sixth hypothesis (H6) states that firms wherein total fixed assets and inventories are more important in their balance sheet experience a higher debt ratio (TOT) vs. a lower one (POT). 
Credit risk $(R I S)$, a probability of default $(p)$ of the firm, is obtained from the score $(S)$ with the formula: $p=1 / 1+\exp S$. Score is calculated as follows:

$$
S=0.3665+0.0388^{*} F A+0.3801^{*} F R I+0.0217^{*} C F+0.0524^{*} P+0.0809^{*} N I+0.00495^{*} S P
$$

$S$ denotes the score, FA financial autonomy (Equity / Total assets fund)*100, FRI financial rate of interest (Interest / Net Sales)*100, CF cash flow (Cash flow before distribution / Net Sales + Operating subsidies)*100, $P$ performance (Profit before taxes / Net sales + Operating subsidies)*100, NI net income (Net income / net shareholders' equity)*100 and SP the share of personnel (Personnel costs + Employee participation in profit / value added)*100 (See Altman, 1968; Modrik, 2016).

We classify SMEs in three types of credit risk according to Basel II:

if $p<20 \%$, the company carries low or medium risk (LMR);

if $20 \% \leq p<25 \%$, the company carries strong risk (SR);

if $p \geq 25 \%$, the company carries excessive risk (UR).

We include credit risk thanks to three indicators: LMR dummy, SR dummy and UR dummy. With respect to information asymmetry, low and medium-risk and high-risk businesses should be less leveraged than excessive risk businesses. The seventh hypothesis (H7) is stated as follows: credit risk has a negative influence on debt, according to TOT as well as POT.

The dilution or the concentration of ownership upon the capital of a company (OWN) characterizes respectively that company as independent or as owned by a group. It is worth noticing that Kremp and Philippon (2008) observe a large increase in the share of SMEs belonging to a group: from $20 \%$ (1997) to $50 \%{ }^{\circ}$ (2006). We include ownership thanks to two dummy variables: independent dummy and group-owned dummy. The control of the capital structure and debt strategy are less constrained for independent than for group-owned businesses. However, as for the average effective rate and administrative costs whatever the credit method (fixed rate, overdraft or lease), debt for independent SMEs proves more expensive than for those belonging to a group, (Chai and Nguyen, 2011). Our eighth hypothesis (H8) is stated as follows: with respect to group-owned businesses, independent businesses experience a higher (TOT) vs. a lower (POT) debt ratio.

\subsection{Sample design and descriptive statistics}

Data were collected from 1,085,000 French firms in the DIANE database, which are available over ten years. We assume that biases remain roughly constant overtime; hence, the database enables to make relevant comparisons with other comparable French studies in order to highlight some stylised facts.

We have not tested "extended" POT that distinguishes rationed SMEs using trade credit from non-rationed SMEs accessing bank credit (see the disequilibrium model in Cabo-Valverde, Rodriguez-Fernandez \& Udell, 2009). Credit rationing in France was underway before the 2008 financial crisis occurred; it affects younger SMEs, which fall out of our scope, that experience high growth rate but lack cash flow and collateral (Alexandre \& Stephan-Buisson, 2014).

The selection of the sample complies with the definition of SMEs coined by the European Commission in 2005: SME is any business that employs less than 250 people, with total assets from $€ 2$ million (minimum) up to €43 million (maximum), and sales turnover from €2 million (minimum) up to $€ 50$ million (maximum). We selected firms according to the classification of business activity (NAF level 60) from the French statistical office (INSEE), which includes all manufacturing, trade and services establishments; agriculture and financial activities, associations, as well as holding and real estate companies without employees are excluded (MEF, 2002). All financial data are updated and available for nine consecutive years [2002, 2010]. Our balanced panel of 2,370 SMEs comprises 21,330 observations over almost a decade.

Regarding the distribution by size and categories of SMEs as of year 2010, small enterprises (10-49 employees) account for nearly two-thirds (64.60\%), micro-enterprises (17.34\%) and midsize enterprises $(18.06 \%)$ represent an almost equivalent share. As for the distribution according to industry, SMEs operating in trade and services account for $55 \%$, whereas in building \& construction and manufacturing they account for nearly $45 \%$ of the sample (See Table A2 in the Appendix).

The overall debt ratio for all selected SMEs is 57\%. Midsize companies are more leveraged (60.94\%) than micro-enterprises (56.78\%) and small firms (55.78\%). Hence, the relationship between size and the debt ratio is non-linear (U shaped). 
Equity is the primary source of funding for SMEs: $40.38 \%$ of total liabilities for microenterprises, $41.53 \%$ for small firms and $35.17 \%$ for midsize enterprises. The relationship between the share of equity in total assets and size of the firm displays a non-linear (U shaped) curve.

Trade credit is the second largest source of funding and account for over one quarter of the SMEs liabilities: $24 \%$ for micro-enterprises, $24.75 \%$ for small firms and $25.53 \%$ for midsize enterprises. Trade credit increases with size and there is a linear positive relationship.

Debt is the third largest funding source for SMEs: $16.21 \%$ of liabilities for micro-enterprises, $14.78 \%$ for small firms and $15.14 \%$ for mid enterprises. There is a strong variance as regards debt (including short-term). The relationship between average financial debt and the size of business displays a non-linear (U-shaped) curve.

These patterns suggest that the sequence reversal between equity and debt runs against POT, whereas it matches rather well transaction costs economics. Adding trade credit with (financial) debt to gauge overall debt, the broader picture is as follows: equity ranks first over overall debt for both the micro and small businesses running against POT, albeit it ranks second for midsize firms in accordance with POT.

According to the distribution of SMEs by their legal status recorded in Table 2, all stock companies account for three quarters of the sample. Simple stock companies represent more than half the sample and are rather small firms: their average debt ratio during the period is the same regardless of the category (or size) and equals the average debt ratio of all companies. Similar characteristics apply to other stock companies, representing less than one in six SMEs. Limited Liability Companies, one out of four SMEs, are rather microenterprises; their debt ratio declines with size (small and midsize firms have less debt) but remains above the average debt ratio of all companies. The reverse relationship between the size and legal status in terms of debt is obvious for less-capitalized companies that are also smaller as for Limited Liability Companies, whereas there is a nonlinear (U shaped) relationship with respect to stock companies. The distribution of ownership includes 806 independent SMEs, one-third (34.01\%) of the sample, whereas 1,564 SMEs owned by a group represents about two-thirds (65.99\%). Table A3 (in the Appendix) details the distribution of SMEs according to their legal status and debt ratio over 2002-2010.

\section{Table 2. Distribution of SMEs categories according to their legal status}

\begin{tabular}{|c|c|c|c|c|c|}
\hline $\begin{array}{l}\text { Legal status } \\
\text { Category }\end{array}$ & & $\begin{array}{c}\text { Micro } \\
\text { enterprises }\end{array}$ & $\begin{array}{c}\text { Small } \\
\text { enterprises }\end{array}$ & $\begin{array}{l}\text { Midsize } \\
\text { enterprises }\end{array}$ & Total (\%) \\
\hline $\begin{array}{l}\text { Partnership + Real estate company + } \\
\text { Cooperative }\end{array}$ & $\mathrm{N}(\%)$ & $1(0.04)$ & $12(0.5)$ & $4(0.16)$ & $17(.7)$ \\
\hline $\begin{array}{l}\text { Limited liability company. + Single member } \\
\text { limited liability company + Personal } \\
\text { business }\end{array}$ & $\mathrm{N}(\%)$ & $147(6.2)$ & 408 (17.21) & $46(1.95)$ & $601(25.36)$ \\
\hline $\begin{array}{l}\text { Simple stock company + Personal stock } \\
\text { company + Stock partnership }\end{array}$ & $\mathrm{N}(\%)$ & $203(8.56)$ & $837(35.31)$ & $295(12.45)$ & $1,335(56.32)$ \\
\hline $\begin{array}{l}\text { Stock company + company with executive } \\
\text { board }\end{array}$ & $\mathrm{N}(\%)$ & $60(2.53)$ & $274(11.56)$ & $83(3.5)$ & 417 (17.59) \\
\hline Total & $\mathrm{N}(\%)$ & 411 (17.3) & $1531(64.6)$ & $428(18.1)$ & $2,370(100.0)$ \\
\hline
\end{tabular}

Source: Authors from DIANE

Table 3 records trends according to the category of risk over 2002-2010. The number of excessive risk (UR) businesses increases by 40.5\%, rising from 363 in 2007 to 510 in 2010. Similarly, the number of high-risk (SR) enterprises increases by 10.22\%, from 538 in 2007 to 593 in 2010. Conversely, the number of low and medium risk $(L M R)$ businesses declines by $13.75 \%$, from 1,469 in 2007 to 1,267 in 2010 . These trends highlight the impact of the financial crisis upon mature SMEs in our panel.

Table 3. Trends in businesses according to the category of risk

\begin{tabular}{lccccccccc} 
& $\mathbf{2 0 0 2}$ & $\mathbf{2 0 0 3}$ & $\mathbf{2 0 0 4}$ & $\mathbf{2 0 0 5}$ & $\mathbf{2 0 0 6}$ & $\mathbf{2 0 0 7}$ & $\mathbf{2 0 0 8}$ & $\mathbf{2 0 0 9}$ & $\mathbf{2 0 1 0}$ \\
\hline Low and medium risk $(L M R)$ & 1503 & 1422 & 1412 & 1397 & 1375 & 1469 & 1382 & 1306 & 1267 \\
Strong risk $(S R)$ & 516 & 548 & 554 & 572 & 576 & 538 & 587 & 570 & 593 \\
Unacceptable risk $(U R)$ & 351 & 400 & 404 & 401 & 419 & 363 & 401 & 494 & 510 \\
\hline
\end{tabular}

Source: Authors from DIANE 
Table 4 records the distribution of SMEs according to risk and the debt ratio, which is a $15 \%$ average for the overall sample. The average debt ratio for micro-enterprises is $16 \%$, whereas it is $15 \%$ for small and midsize enterprises. Thus, debt is a decreasing function of size and an increasing function of risk. As for low and medium risk $(L M R)$, micro enterprises display a higher debt ratio $(16 \%)$ than small and midsize enterprises (13\%). As for the transition to high risk (SR), the debt ratio declines for micro enterprises (15\%) whereas it increases for small business $(15 \%)$ and midsize enterprises (16\%). The debt ratio is higher $(20 \%)$ with regard to excessive risk (UR) and substantially identical for all enterprises.

\begin{tabular}{|c|c|c|c|c|c|c|c|c|}
\hline \multirow{2}{*}{$\begin{array}{l}\text { Risk } \\
\text { Debt ratio }\end{array}$} & \multicolumn{2}{|c|}{ Microenterprises } & \multicolumn{2}{|c|}{ Small enterprises } & \multicolumn{2}{|c|}{$\begin{array}{c}\text { Midsize } \\
\text { enterprises }\end{array}$} & \multicolumn{2}{|c|}{$\begin{array}{c}\text { Total } \\
\text { observations }\end{array}$} \\
\hline & Average & $\mathbf{N}$ & Average & $\mathbf{N}$ & Average & $\mathbf{N}$ & Average & $\mathbf{N}$ \\
\hline Low-medium risk (LMR) & $16 \%$ & 5,059 & $13 \%$ & 5,902 & $13 \%$ & 1,572 & $14 \%$ & 12,533 \\
\hline Strong risk (SR) & $15 \%$ & 1,756 & $15 \%$ & 2,364 & $16 \%$ & 934 & $15 \%$ & 5,054 \\
\hline Unacceptable risk (UR) & $20 \%$ & 1,246 & $20 \%$ & 1,711 & $19 \%$ & 786 & $20 \%$ & 3,743 \\
\hline Total & $16 \%$ & 8,061 & $15 \%$ & 9,977 & $15 \%$ & 3,292 & $15 \%$ & 21,330 \\
\hline
\end{tabular}

Source: Authors from DIANE

\subsection{The dynamic balanced panel model}

We design our model with the generalised method of moments (GMM) This dynamic estimation technique is based on instrumentation, the issue being to find the instruments, which are both valid (not correlated with the error terms) and robust (strongly correlated with the explanatory variables). The first difference estimator (GMM-DIF) takes for each period the first difference of the estimated equation to remove specific effects; then it instruments explanatory variables of the equation in first difference with their values in level lagged by one period or more (Arellano and Bond, 1991). The system estimator (GMM-SYS) combines the first difference equations with the level equations wherein the variables are instrumented by their first difference and outperforms the GMM-DIF estimator (Blundell \& Bond, 1998).

Two tests are associated with the estimator of GMM dynamic panel. The Sargan-Hansen over-identification test takes care of the validity of lagged variables chosen as instruments; Statistics following this test, under the null hypothesis $\mathrm{HO}$ of validity of the combination of instruments chosen, a khi2 law with $p k$ degrees of freedom where $p$ is the number of instrumental variables and $k$ is the number of estimated coefficients in the model. The Arellano \& Bond autocorrelation test takes care of the absence of autocorrelation of second order errors in the difference equation for the null HO hypothesis.

In the model we use the following variables as instruments: their current values for exogenous variables such as age (Age), default risk indicator $(R I S)$ and the independence of the company $(O W N)$; their lagged values (at least one period) were used for predetermined or weakly exogenous variables that are possibly influenced by past values of the dependent variable, although uncorrelated with the error term such as GAR (lag1); their lagged values (at least two periods) were used for endogenous variables such DRt-1 (lag3) PROF (lag3), GO (lag2), TC (lag2). Thus, the dynamic model that we test thereafter is designed as follows:

$$
\begin{aligned}
D F_{i t}=\alpha_{0}+ & \alpha_{1} D F_{i t-1}+\alpha_{2} A G E_{i t}+\alpha_{3} P_{R O F_{i t}}+\alpha_{4} O C_{i t}+\alpha_{5} C I E_{i t}+\alpha_{6} G A R_{i t} \\
& +\alpha_{7} \text { DummyLMR }_{i t}+\alpha_{8} \text { DummySR }_{i t}+\alpha_{9} \text { Dummyindependent }_{i t}+\varepsilon_{i t}
\end{aligned}
$$

\section{Results}

Table 5 presents the dynamic estimates in system with associated tests. Sargan test and Arellano \& Bond disturbances autocorrelation AR(1) and AR(2) validate the combination of instruments and reject the presence of second order autocorrelation upon both the overall sample and each category (or size) of SMEs. According to a breakdown by period, estimates show that the financial structure of SMEs is not neutral. The tested explanatory variables are very significant $(p<0.01)$ and affect the debt ratio for all SMEs as well as for the categories of micro, small and midsize enterprises. 
Table 5. Outcomes from dynamic estimates (GMM-SYS) of the debt ratio

\begin{tabular}{|c|c|c|c|c|c|c|c|c|}
\hline & \multicolumn{4}{|c|}{ 2003-2007 } & \multicolumn{4}{|c|}{$2008-2010$} \\
\hline & SMES & Micro & Small & Midsize & SMEs & Micro & Small & Midsize \\
\hline \multirow{2}{*}{ DRt-1 } & $0,596^{* * *}$ & $0,536^{* * *}$ & $0,609^{* * *}$ & $0,524^{* * *}$ & $0,705^{* * *}$ & $0,547^{* * *}$ & $0,752^{* * *}$ & $0,619 * * *$ \\
\hline & $(0,015)$ & $(0,022)$ & $(0,028)$ & $(0,041)$ & $(0,029)$ & $(0,050)$ & $(0,052)$ & $(0,083)$ \\
\hline \multirow{2}{*}{$A G E$} & $0,000^{* * *}$ & $-0,001^{* * *}$ & $0,000 * * *$ & $-0,001^{* * *}$ & $0,000^{* * *}$ & $-0,001 * * *$ & $-0,001^{* * *}$ & $0,000 * * *$ \\
\hline & $(0,000)$ & $(0,000)$ & $(0,000)$ & $(0,000)$ & $(0,000)$ & $(0,000)$ & $(0,000)$ & $(0,000)$ \\
\hline \multirow{2}{*}{ PROF } & 0,053 & $-0,454^{* * *}$ & $0,318^{* * *}$ & $-0,067$ & $0,326^{* * *}$ & $-0,366^{* * *}$ & 0,174 & 0,051 \\
\hline & $(0,073)$ & $(0,092)$ & $(0,139)$ & $(0,108)$ & $(0,068)$ & $(0,130)$ & $(0,126)$ & $(0,078)$ \\
\hline \multirow{2}{*}{ GO } & $0,276^{* * *}$ & $0,366^{* * *}$ & $0,347^{* * *}$ & $-0,167$ & $0,238^{* * *}$ & 0,123 & $-0,341^{* * *}$ & $0,213^{* * *}$ \\
\hline & $(0,054)$ & $(0,072)$ & $(0,084)$ & $(0,131)$ & $(0,059)$ & $(0,122)$ & $(0,099)$ & $(0,099)$ \\
\hline \multirow{2}{*}{$T C$} & $-0,139 * * *$ & $-0,178^{* * *}$ & 0,041 & $-0,067$ & $0,141^{* * *}$ & $0,247^{* * *}$ & $0,187^{* * *}$ & $0,209 * * *$ \\
\hline & $(0,028)$ & $(0,052)$ & $(0,052)$ & $(0,051)$ & $(0,019)$ & $(0,031)$ & $(0,032)$ & $(0,044)$ \\
\hline \multirow{2}{*}{$G A R$} & $0,241^{* * *}$ & $0,273^{* * *}$ & $0,375^{* * *}$ & $0,296^{* * *}$ & $0,445^{* * *}$ & $0,571^{* * *}$ & $0,283^{* * *}$ & $0,235^{* * *}$ \\
\hline & $(0,016)$ & $(0,031)$ & $(0,037)$ & $(0,041)$ & $(0,020)$ & $(0,034)$ & $(0,043)$ & $(0,032)$ \\
\hline$R I S$ & $-0,028^{* * *}$ & $0,035^{* * *}$ & $-0,059 * * *$ & $-0,021 * * *$ & $-0,043^{* * *}$ & $0,035^{* * *}$ & $-0,025^{* * *}$ & $-0,038^{* * *}$ \\
\hline Dummy LMR & $(0,008)$ & $(0,011)$ & $(0,015)$ & $(0,011)$ & $(0,008)$ & $(0,015)$ & $(0,012)$ & $(0,009)$ \\
\hline RIS & $-0,018^{* * *}$ & 0,002 & $-0,033^{* * *}$ & $-0,007$ & $-0,025^{* * *}$ & 0,001 & $-0,015^{* * *}$ & $-0,027^{* * *}$ \\
\hline Dummy SR & $(0,004)$ & $(0,005)$ & $(0,006)$ & $(0,006)$ & $(0,004)$ & $(0,006)$ & $(0,005)$ & $(0,006)$ \\
\hline oWN Dummy & $-0,004^{* * *}$ & $-0,012^{* * *}$ & 0,000 & 0,002 & $-0,003$ & $-0,005$ & 0,002 & $0,009^{* * *}$ \\
\hline independent & $(0,002)$ & $(0,003)$ & $(0,002)$ & $(0,003)$ & $(0,002)$ & $(0,004)$ & $(0,002)$ & $(0,004)$ \\
\hline \multirow{2}{*}{ Constant } & $-0,003$ & 0,014 & $-0,073^{* * *}$ & 0,010 & $-0,115^{* * *}$ & $-0,105^{* * *}$ & $-0,036^{* *}$ & $-0,024$ \\
\hline & $(0,008)$ & $(0,013)$ & $(0,017)$ & $(0,021)$ & $(0,010)$ & $(0,023)$ & $(0,021)$ & $(0,022)$ \\
\hline $\begin{array}{c}\text { Total } \\
\text { observations }\end{array}$ & 14220 & 5309 & 6710 & 2201 & 7110 & 2752 & 3267 & 1091 \\
\hline $\mathrm{AR}(1)$ & 26,29 & 14,91 & 15,92 & $-9,96$ & 17,09 & $-7,02$ & 11,06 & $-3,98$ \\
\hline $\mathrm{p}$-value & 0,000 & 0,000 & 0,000 & 0,000 & 0,000 & 0,000 & 0,000 & 0,000 \\
\hline $\mathrm{AR}(2)$ & 2,25 & 1,70 & $-0,58$ & 0,25 & - & - & - & - \\
\hline $\mathrm{p}$-value & 0,024 & 0,088 & 0,561 & 0,800 & - & - & - & - \\
\hline Sargan & 453,78 & 240,72 & 130,24 & 112,43 & 71,26 & 103,58 & 75,62 & 75,06 \\
\hline p-value & 0,000 & 0,000 & 0,000 & 0,000 & 0,000 & 0,000 & 0,000 & 0,000 \\
\hline
\end{tabular}

${ }^{* * *} \mathrm{p}<0.01,{ }^{* *} \mathrm{p}<0.5$ and ${ }^{*} \mathrm{p}<0.1$. (Standard deviation into parentheses).

Source: Authors from DIANE

The lagged variable (DRt-1) is most significant $(\mathrm{p}<0.01)$ and positively correlated with the debt ratio for all SMEs during both periods. Our results do not support the bankruptcy cost theory and therefore invalidate TOT. The coefficients of lagged variables can be interpreted as the expression of adjustment costs upon the level of debt, with particular reference to the impact of non-measurable economic factors (Ziane, 2004) or path-dependency (Coleman, 2014). During the first period (2003-2007), there is an inverted U-shape positive relationship by size of SMEs (micro, small and midsize enterprises), which proves even stronger during the second period (2008-2010). In line with Ziane (2004), $H 1$ hypothesis of a positive relationship is confirmed, albeit not an increasing function of the size of the firm.

The age variable $(A G E)$ is most significant $(\mathrm{p}<0.01)$ and negatively correlated with the debt ratio (approximately $-0.1 \%$ ) and this result applies for each category of SMEs. It refutes the predictions of TOT and the agency theory holding that older firms have a better reputation and more experience, enjoying reduced agency costs thanks to a positive signal. Conversely, it sustains the predictions of POT, whereby the more the company is mature, the more its cash flow increases and the less it resorts to debt financing. $H 2$ hypothesis of a negative relationship between the age of the company and its debt ratio is consistent with the findings of Boussaa (2000), Adaskou \& Adair (2011) as well as Adaskou \& Adair (2015), whereas Ziane (2004) observes an ambiguous effect.

Profitability (PROF) has a positive and significant effect on the debt ratio. Prior to 2008, the positive effect is not significant as for all SMEs. It is most significant $(\mathrm{p}<0.01)$ and respectively negative on micro and positive on small enterprises, whereas it proves negative but insignificant on midsize enterprises. After 2008, the effect is most significant $(\mathrm{p}<0.01)$ ) for all SMEs, being negative for microenterprises favouring the use of internal resources over bank loans and positive although not significant for small and midsize enterprises. As for all SMEs, the result rejects the POT predictions with regard to preference for internal financing, in as much as the company needs less external resources and therefore debt. Conversely, it confirms the predictions of TOT with regard to the use of debt as a means of tax savings and also to reduce agency costs and to signal good corporate financial health to donors. According to categories, microenterprises confirm POT, whereas small and midsize businesses confirm TOT. The $H 3$ hypothesis is invalidated as for all SMEs and during both periods. This positive relationship between profitability and the debt ratio is 
not in accordance with the conclusions of Molay \& Dufour (2010), Adaskou \& Adair (2015) and Ziane (2004).

The impact of growth opportunities $(G O)$ on the debt ratio is most significant $(\mathrm{p}<0.01)$ and positive (24.1\%) for all SMEs and proves stronger for midsize enterprises $(38.1 \%)$. It does not validate TOT that predicts a negative relationship between growth opportunities and the debt ratio due to the existence of agency costs and risk. H4 hypothesis is verified in accordance with the POT predictions: the relationship between growth opportunities and the debt ratio is positive. This finding is consistent with those of Ziane (2004), Dufour \& Molay (2010), Adaskou \& Adair (2011) as well as Adaskou \& Adair (2015).

The effect of the trade credit balance (TC) upon the debt ratio is most significant $(\mathrm{p}<0.01)$ and negative before the crisis as for all SMEs as well as for micro and midsize enterprises, in contrast with the inverted $U$ shape relationship for small businesses: This seems to confirm POT, whereby trade credit is a substitute for financial debt, in accordance with Adaskou \& Adair (2011). After the crisis, there is a positive effect upon all SMEs and each category: the relationship is Ushaped. This seems to confirm TOT, in accordance with Trabelsi (2006) as well as Adaskou \& Adair (2015), who find a positive and significant relationship. H5 hypothesis stating that firms using more trade credit experience a lower debt ratio remains controversial.

Guarantees $(G A R)$ is most significant $(\mathrm{p}<0.01)$ and positively correlated with the debt ratio for all the SMEs, especially micro and small businesses: companies with fixed assets and inventories in their balance sheet are more indebted. Due to the high costs of failure and agency costs associated with granting loans to SMEs, lenders require collateral as a major selection criterion (Lopez-Gracia \& Sogorb-Mira, 2008); it reduces agency costs and triggers greater incentive for creditors to engage in long-maturity interest-bearing loans (Jensen \& Meckling, 1976; Harris \& Raviv, 1990). H6 hypothesis is validated. The positive relationship between guarantees and the debt ratio confirms the predictions of TOT. Our result is consistent with those of Ziane (2004), Trabelsi (2006), Adaskou \& Adair (2011), as well as Adaskou \& Adair (2015).

As for credit risk $(R I S), U R$ dummy (excessive risk) standing as a reference. Throughout both periods, dummies $L M R$ (low and medium risk) and $S R$ (high risk) are significant and slightly negative for all SMEs and according to categories. Companies with low or medium risk and high risk are less indebted than excessive risk businesses. This result may due to self-selection prompting these companies to avoid debt and leverage other funding sources such as trade credit and selffinancing. $H 7$ hypothesis is validated: credit risk negatively influences the debt ratio, which proves compatible with TOT as well as with POT.

Ownership $(O W N)$ takes care of the fact that the company is either independent or owned by a major shareholder (group), which is regarded as a reference. The latter category experiences less funding constraints than the former one in as much as belonging to a group is a good signal to donors. Before 2008, the dummy independent is significant $(\mathrm{p}<0.01)$ and slightly negative for all SMEs as well as for microenterprises; it is positive but not significant for small and midsize enterprises. After 2008, the relationship proves negative but not significant as for all SMEs and micro-enterprises; it is positive for small and midsize enterprises. $H 8$ hypothesis is validated, independent companies are less indebted than group-owned enterprises. This seems to confirm POT.

\section{Discussion and conclusion}

We focused on the determinants of debt ratio upon a large balanced panel of 2,370 French SMEs observed for nine years [2002-2010], broken down into two periods [2003-2007] and [20082010]. Our first objective was to identify to what extent trade-off theory (TOT) vs. pecking order theory (POT) explains best the financial behaviour of mature SMEs. Our second objective was to study the impact of the 2008 crisis on the financing structure of SMEs and the lasting effect of the explanatory variables determining the debt ratio. According to the GMM estimates, we reject the indifference assumption as for the choice of capital structure, concluding that both theories only partly explain the borrowing behaviour of SMEs.

Our study supports most but not all findings from previous studies on the capital structure of SMEs in France. First, the relationship between the debt ratio and lagged debt ratio is positive for all SMEs before and after 2008, with an inverted U shape according to the size of SMEs. It reverses the bankruptcy costs theory and seems to confirm POT, although it may also suggest the existence of adjustment costs upon the level of debt with regard to transaction costs. Second, the relationship between age and the debt ratio lacks interpretation: all coefficients are nil for the various categories of SME. Third, profitability has a positive impact on the debt ratio of all SMEs especially after 2008; according to categories, microenterprises confirm POT, whereas small and midsize businesses confirm TOT. Prior the crisis, the influence of profitability is negative upon micro and midsize 
enterprises, whereas it is positive upon small businesses. Fourth, growth opportunities have a positive influence on the debt ratio during both periods and for all SMEs in accordance with POT. Prior to 2008, it is positive and significant upon micro and small enterprises, except for midsize enterprises. After 2008, it is positive on micro and midsize enterprises but proves negative upon small businesses. Fifth, trade credit has a negative effect on the debt ratio before 2008 upon all SMEs except for small businesses (inverted U shape relationship), which seems to confirm POT. After 2008, the positive effect upon all SMEs and each category (U-shaped relationship) seems to confirm TOT. Sixth, guarantees confirm the prediction of TOT. Seventh, with regard to credit risk, low-and medium-risk as well as high-risk companies leverage less than excessive-risk businesses, the number of which rises after 2008. This result seems to confirm both TOT and POT. Eighth, independent SMEs are less indebted than group-owned enterprises, which tends to confirm POT.

POT passes the test better than does TOT, although some evidence supports each theory. In agreement with Harris \& Raviv (1991) and Myers (2001), we join the conclusion of Frank \& Goyal (2008) that no currently available theory explains alone the determination of the capital structure of SMEs.

Our study faces limitations inherent to the nature of book accounting data (Welch, 2002), the approximate measurement of some variables as well as the heterogeneity of SMEs. Due to the selection of mature firms, our balanced panel cannot display a representative picture of French SMEs. The use of a dynamic panel corrects the endogeneity bias and thus contributes to the development of more robust stylised facts.

\section{Acknowledgment}

The authors gratefully acknowledge comment from participants to the workshop wherein the paper was presented at the $4^{\text {th }}$ Applied Economics and Finance Conference (JEFA'18) May 1112, 2018, University of Mahdia, Tunisia

\section{Funding}

The authors received no direct funding for this research.

\section{Citation information}

Adair, P., \& Adaskou, M. (2018). The capital structure of mature French SMEs and impact of the great recession: A dynamic panel data analysis (2002-2010). Economics, Management and Sustainability, 3(2), 60-75. doi:10.14254/jems.2018.3-2.5.

\section{References}

Adair, P. \& Adaskou, M. (2015). Trade-off theory vs. pecking order theory and the determinants of corporate leverage: Evidence from a panel data analysis upon French SMEs (2002-2010). Cogent Economics and Finance, 3(1), 1-9.

Adair, P. \& Adaskou, M. (2011). Théories financières et endettement des PME en France: une analyse en panel (2000-2004) [Financial theories and the debt of SMEs in France: A panel data analysis (2000-2004)]. Revue internationale PME, 24(2), 137-171.

Alexandre, H. \& Stéphan-Buisson, H. (2014). L'impact de la crise de 2008 sur le rationnement du crédit des PME françaises [The impact of the 2008 crisis upon credit rationing of the French SMEs]. Revue Internationale PME, 27(2), 95-113.

Altman, E. (1968). Financial ratios, discriminant analysis and the prediction of corporate bankruptcy. Journal of Finance, 23(4), 589-609.

Ang, J.S. (1991). Small business uniqueness and the theory of financial management. Journal of Small Business Finance, 1(1), 1-13.

Arellano, M. \& Bond, S. (1991). Some Tests of Specification for Panel Data: Monte Carlo Evidence and an Application to Employment Equations. Review of Economic Studies, 58, 277-297.

Barberis, N. \& Thaler, R. (2003). A survey of behavioral finance. In G. Constantinides, M. Harris \& R. Stulzch (Eds.), Handbook of the Economics of Finance (pp. 1052-1119). Amsterdam: Elsevier.

Berger, A.N. \& Udell, G.F. (1990). Collateral, loan quality and bank risk. Journal of Monetary Economics, 25, 21-42. 
Besanko, D. \& Thakor, A.V. (1987). Collateral and rationing: Sorting equilibria in monopolistic and competitive credit markets. International Economic Review, 28, 671-689.

Blundell, R. \& Bond, S. (1998). Initial Conditions and Moment Restrictions in Dynamic Panel Dated Models. Journal of Econometrics, 87, 115-143.

Bourdieu, J. \& Colin-Sédillot, B. (1993). Structure du capital et coûts d'information : le cas des entreprises françaises à la fin des années quatre-vingt [Capital structure and information costs: The case of French companies in the late eighties]. Economie et statistique, 268, 87100.

Boussaa, N. (2000). Théorie financière contemporaine et PME : une analyse économique sur données de panel [Contemporary financial theory and SMEs: An economic analysis on panel data]. Unpublished PhD Thesis. Université Paris 10, Nanterre, France.

Brealey, R., Myers, S. \& Allen, F. (2017). Principles of corporate finance (10 th ed.). New York: The McGraw-Hill/Irwin Series in Finance, Insurance, and Real Estate.

Brounen, D., De Jong, A. \& Koedijk, K. (2004). Corporate finance in Europe: Confronting theory with practice. Financial Management, 33, 71-101.

Carbo-Valverde, S., Rodriguez-Fernandez, F. \& Udell, G.F. (2009). Bank market power and SME financing constraints. Review of Finance, 13(2), 309-340.

Coleman, L. (2014). Involuntary corporate finance: the dominance of history in decisions. Applied Economics, 46(33), 4104-4115.

Colot, V. \& Michel P-A. (1996). Vers une théorie financière adaptée aux PME. Réflexion sur une science en genèse" [Towards a financial theory adapted to SMEs. Reflecting on a science genesis]. Revue Internationale PME, 9(1), 143-166.

Chai, F. \& Nguyen, D.B. (2011). Le coût du crédit aux entreprises selon leur catégorie [The cost of credit for enterprises according to their category]. Bulletin de la Banque de France, 185, 3145 .

Chittenden, F., Hall, G. \& Hutchinson, P. (1996). Small firm growth, access to capital markets and financial structure: Review of issues and an empirical investigation. Small Business Economics, 8, 59-67.

Cieply, S. (1997). Spécificité financière des PME et nouvelles théories du financement : une application à un échantillon d'entreprises françaises [The financial specificity of SMEs and new financing theories: An application to a sample of French companies]. Unpublished PhD thesis. Université Lyon 2, Lyon, France.

Daskalakis, N. \& Psillaki, M. (2007). Do country or firm factors explain capital structure? Evidence from SMEs in France and Greece. Applied Financial Economics, 18, 87-97.

Dietsch, M. \& Kremp, E. (1998). Le crédit interentreprises bénéficie plus aux grandes entreprises qu'aux PME" [Trade credit benefits large companies rather than SMEs]. Economie et statistique, 314, 25-37.

Dufour, D. \& Molay, E. (2010). La structure financière des PME françaises : une analyse sectorielle sur données de panel' [The financial structure of French SMEs: A sector analysis on panel data]. Paper presented at the $31^{\text {st }}$ Conference of the Francophone Accounting Association: Crises et nouvelles problématiques de la Valeur (pp. 1-18). Nice: France.

European Commission (2003). SMEs and Access to Finance. Observatory of European SMEs 2. Brussels: Belgium.

Frank, M.Z. \& Goyal, V.K. (2003). Testing the pecking order theory of capital structure. Journal of Financial Economics, 67, 217-248.

Frank, M.Z. \& Goyal, V.K. (2008). Trade-off and pecking order theories of debt. In B. Espen (Ed.), Handbook of empirical corporate finance 2 (pp. 135-202). Amsterdam: Elsevier.

Gurău, C., Lahiani, A. Seran, T-L. \& Van Hoang, T.H. (2018). Do crises impact capital structure? A study of French micro-enterprises. Small Business Economics, 50(1), 181-199.

Harris, M. \& Raviv, A. (1990). Capital structure and the informational role of debt. The Journal of Finance, 45, 321-349.

Harris, M. \& Raviv, A. (1991). The theory of capital structure. The Journal of Finance, 46, 297-355. 
Holmes, S. \& Kent, P. (1991). An Empirical Analysis of the Financial Structure of Small and Large Australian Manufacturing Enterprises. Journal of Small Business Finance, 1(2), 141-154.

Jensen, M.C. \& Meckling, W. (1976). Theory of the firm: Managerial behavior, agency costs and ownership structure. Journal of Financial Economics, 3, 305-360.

Kremp, E. \& Phillippon, T. (2008). Changing patterns of firm ownership and financing: Evidence from SMEs in France. Paris: Banque de France.

KPMG (2012). Panorama de l'évolution des PME depuis 10 ans [Overview of the evolution of SMEs in the past 10 years]. Paris: CGPME.

Leary, M.T. \& Roberts, M.R. (2010). The pecking order, debt capacity, and information asymmetry. Journal of Financial Economics, 95, 332-355.

Leary, M.T. \& Roberts, M.R. (2012). Do peer firms affect corporate financial policy? The Journal of Finance, 69, 139-178.

López-Gracia, J. \& Sogorb-Mira, F. (2008). Testing trade-off and pecking order theories financing SMEs. Small Business Economics, 31, 117-136.

MEF (2002) Les chiffres-clefs des PME [Key data for SMEs]. Etudes et Statistiques, Paris, Ministère de l'Economie et des Finances.

Miller, M.H. (1977). Debt and taxes. The Journal of Finance, 32, 261-275.

Modigliani, F. \& Mille,r M.H. (1958). The cost of capital, corporation finance and the theory of investment. American Economic Review, 48, 261-297.

Modigliani, F. \& Miller, M.H. (1963). Corporate income taxes and the cost of capital: A correction. American Economic Review, 53, 433-443.

Modrik, K. (2016). Evaluation du risque de crédit des PME françaises internationalisées [The credit risk assessment of globalised French SMEs] Unpublished PhD thesis. Université d'Angers, Angers, France.

Myers, S.C. (1977). Determinants of corporate borrowing. Journal of Financial Economics, 5, 147175.

Myers, S.C. (2001). Capital structure. Journal of Economic Perspectives, 15, 81-102.

Myers, S.C. \& Majluf, N.S. (1984). Corporate financing and investment decisions when firms have information that investors do not have. Journal of Financial Economics, 13, 187-221.

ECB (2009). Survey on the access to finance of Small and Medium-Sized Enterprises in the Euro area. European Central Bank. Frankfurt. September

OSEO (2011). PME 2011 [SMEs 2011]. Paris: Les études de l’Observatoire des PME.

Petersen, M.A. \& Rajan, R.G. (1994). The benefits of lending relationships: Evidence from small business data. The Journal of Finance, 49, 3-37.

Pettit, R.R., \& Singer, R.F. (1985). Small Business Finance: A Research Agenda. Financial Management, 14(3), 47-60.

Psillaki, M., Tsolas, I.E. \& Margaritis, D. (2010). Evaluation of credit risk based on firm performance". European Journal of Operational Research, 201, 873-881.

Rajan, R.G. \& Zingales, L. (1995). What do we know about capital structure? Some evidence from international data. The Journal of Finance, 50, 1421-1460.

Shyam-Sunder, L. \& Myers, S.C. (1999). Testing static trade-off against pecking order models of capital structure. Journal of Financial Economics, 51, 219-244.

Stiglitz, J.E. (1969). A re-examination of the Modigliani-Miller theorem. American Economic Review, 59, 784-793.

Titman, S. \& Wessels, R. (1988). The determinants of capital structure choice. The Journal of Finance, 43(1), 1-19.

Trabelsi, A. (2006). Les déterminants de la structure du capital et les particularités du financement dans les PME : une étude sur données françaises [Determinants of capital structure and the financing particularities of SMEs: A study on French data] Unpublished PhD thesis. Université Paris IX Dauphine, Paris, France. 
Welch, I. (2002). Colombus' egg: The real determinant of capital structure. NBER: Working Paper 8782. http://www.nber.org/papers/w8782

Williamson, O.E. (1988). Corporate finance and corporate governance. The Journal of Finance, 43, 567-591.

Ziane, Y. (2004). Structure financière, relations bancaires de long terme et financement interentreprises des PME françaises [Financial structure, long-term banking relationships and the intercompany financing of French SMEs] Unpublished PhD thesis. Universite Paris 10, Nanterre, France. 


\section{Appendix. Supplementary material}

\begin{tabular}{|c|c|c|}
\hline Authors & Sample, country, period and techniques & Outcomes \\
\hline Bédué (1997) & $\begin{array}{l}\text { Balanced panel of 1,387 firms (DIANE); France, } \\
\text { 1989-1993; OLS estimators and Between }\end{array}$ & $\begin{array}{l}\text { POT is validated. Agency theory is } \\
\text { verified. Emphasis is upon the role of } \\
\text { collateral in the credit relationship. }\end{array}$ \\
\hline Boussâa (2000) & $\begin{array}{l}\text { Balanced panel of 1,712 SMEs (DIANE); } \\
\text { France, 1991-1995; multivariate analysis and } \\
\text { econometric analysis (OLS, Within and Between) }\end{array}$ & $\begin{array}{l}\text { POT and signal theory explain the } \\
\text { financial structure of SMEs. Trade credit } \\
\text { reduces information asymmetry. }\end{array}$ \\
\hline Ziane (2004) & $\begin{array}{l}\text { Balanced panel of 2,551 SMEs (DIANE); France, } \\
\text { 1994-2001; estimate the moments (GMM) }\end{array}$ & $\begin{array}{l}\text { POT is most common but not exclusive } \\
\text { from TOT. }\end{array}$ \\
\hline Trabelsi (2006) & $\begin{array}{l}\text { Balanced panel of 1,898 SMEs (DIANE); France, } \\
\text { 1995-2002; OLS }\end{array}$ & POT and TOT are compatible. \\
\hline $\begin{array}{l}\text { Daskalakis \& Psillaki } \\
\text { (2007) }\end{array}$ & $\begin{array}{l}\text { Balanced panel: } 320 \text { SMEs (Italy); } 52 \text { firms } \\
\text { (Portugal); 1,252 firms (Greece) and 2,006 SMEs } \\
\text { (France); 1997-2002. }\end{array}$ & POT is validated. \\
\hline Bellettre (2010) & $\begin{array}{l}\text { Unbalanced panel of } 56,605 \text { micro-enterprises } \\
\text { (DIANE); France, 1998-2006; panel model with } \\
\text { fixed effects and instrumental variables. }\end{array}$ & $\begin{array}{l}\text { POT does not explain the preference of } \\
\text { micro-enterprises for debt, as compared } \\
\text { to current accounts. }\end{array}$ \\
\hline Dufour \& Molay (2010) & $\begin{array}{l}\text { Balanced panel of } 1,535 \text { SMEs (DIANE), France, } \\
2000-2007 \text {; OLS, generalized least squares with } \\
\text { fixed effects or random effects; results associated } \\
\text { with the best specification. }\end{array}$ & $\begin{array}{l}\text { TOT is validated, but POT (semi-strong } \\
\text { version) cannot be rejected. Change in } \\
\text { debt depends on the funding gap. }\end{array}$ \\
\hline Adair \& Adaskou (2011) & $\begin{array}{l}\text { Balanced panel of 1,520 SMEs (DIANE), } \\
\text { France, 2000-2004; OLS, Within, QGLS and } \\
\text { instrumental variables. }\end{array}$ & $\begin{array}{l}\text { POT and TOT are validated according to } \\
\text { variables, albeit some remain } \\
\text { unexplained. POT is slightly better } \\
\text { validated }\end{array}$ \\
\hline Adair \& Adaskou (2015) & $\begin{array}{l}\text { Balanced panel of 2,370 SMEs (DIANE), France, } \\
\text { 2002-2010; OLS, Within, QGLS and instrumental } \\
\text { variables. }\end{array}$ & $\begin{array}{l}\text { POT and TOT are validated according to } \\
\text { variables, albeit some remain } \\
\text { unexplained. POT is slightly better } \\
\text { validated }\end{array}$ \\
\hline Gurău et al. (2018) & $\begin{array}{l}\text { Unbalanced panel of } 4,945 \text { micro-enterprises } \\
\text { (DIANE); France, 2003-2013; LSDV and principal } \\
\text { component analysis }\end{array}$ & $\begin{array}{l}\text { POT is the most relevant theory for } \\
\text { predicting the financial decisions of } \\
\text { these firms, especially debt. }\end{array}$ \\
\hline
\end{tabular}

Source: Authors

\section{Table A2. Distribution of SMEs by size according to industry (year 2010)}

\begin{tabular}{|c|c|c|c|c|c|c|}
\hline Size & $\mathrm{Bu}$ & \& construction & Manufacturing & Trade & Services & Total \\
\hline \multirow{4}{*}{$\begin{array}{l}\text { Microentreprises } \\
\text { (<10 employees) }\end{array}$} & $\mathrm{N}$ & 46 & 66 & 200 & 99 & 411 \\
\hline & $\%$ & 1.94 & 2.78 & 8.44 & 4.18 & 17.34 \\
\hline & (\% row) & (11.19) & $(16.06)$ & $(48.66)$ & (24.09) & \\
\hline & (\% column) & $(9.77)$ & (11.22) & $(23.20)$ & (22.05) & \\
\hline \multirow{4}{*}{$\begin{array}{l}\text { Small enterprises } \\
\text { (10-49 employees) }\end{array}$} & $\mathrm{N}$ & 310 & 397 & 560 & 264 & 1,531 \\
\hline & $\%$ & 13.08 & 16.75 & 23.63 & 11.14 & 64.60 \\
\hline & (\% row) & $(20.25)$ & (25.93) & $(36.58)$ & $(17.24)$ & \\
\hline & ( $\%$ column) & (65.82) & $(67.52)$ & $(64.97)$ & $(58.80)$ & \\
\hline \multirow{4}{*}{$\begin{array}{l}\text { Midsize enterprises } \\
\text { (50-249 employees) }\end{array}$} & $\mathrm{N}$ & 115 & 125 & 102 & 86 & 428 \\
\hline & $\%$ & 4.85 & 5.27 & 4.30 & 3.63 & 18.06 \\
\hline & (\% row) & $(26.87)$ & $(29.21)$ & $(23.83)$ & (20.09) & \\
\hline & (\% column) & $(24.42)$ & $(21.26)$ & (11.83) & (19.15) & \\
\hline \multirow{2}{*}{ Total } & $\mathrm{N}$ & 471 & 588 & 862 & 449 & 2,370 \\
\hline & $\%$ & 19.87 & 24.81 & 36.37 & 18.95 & 100.00 \\
\hline
\end{tabular}

Source: Authors from DIANE 
Table A3: distribution of SMEs categories according to their legal status and debt ratio (20022010)

\begin{tabular}{|c|c|c|c|c|c|c|c|c|c|}
\hline & \multicolumn{2}{|c|}{ Micro } & \multicolumn{2}{|c|}{ Small } & \multicolumn{2}{|c|}{ Midsize } & \multicolumn{3}{|c|}{ Total } \\
\hline & \multicolumn{2}{|c|}{ Debt ratio } & \multicolumn{2}{|c|}{ Debt ratio } & \multicolumn{2}{|c|}{ Debt ratio } & \multicolumn{3}{|c|}{ Debt ratio } \\
\hline & Average & $\mathbf{N}$ & Average & $\mathbf{N}$ & Average & $\mathbf{N}$ & Average & $\mathbf{N}$ & $\%$ \\
\hline Legal status & & & & & & & & & \\
\hline Partnership & 0.21 & 23 & 0.35 & 32 & 0.14 & 17 & 0.25 & 72 & $0.34 \%$ \\
\hline Real estate company & 0.34 & 2 & 0.31 & 7 & . & . & 0.32 & 9 & $0.04 \%$ \\
\hline $\begin{array}{l}\text { Cooperative } \\
\text { Sub-total }\end{array}$ & 0.19 & 19 & 0.25 & 23 & 0.14 & 30 & $\begin{array}{c}0.19 \\
(0.225)\end{array}$ & $\begin{array}{c}72 \\
(153)\end{array}$ & $\begin{array}{c}0.34 \% \\
(0.72 \%)\end{array}$ \\
\hline $\begin{array}{l}\text { Limited liability } \\
\text { company }\end{array}$ & 0.18 & 2,818 & 0.17 & 1,878 & 0.13 & 200 & 0.17 & 4,896 & $22.95 \%$ \\
\hline $\begin{array}{c}\text { Single member limited } \\
\text { liability cy }\end{array}$ & 0.20 & 277 & 0.14 & 189 & 0.13 & 38 & 0.17 & 504 & $2.36 \%$ \\
\hline Personal business & 0.12 & 4 & 0.05 & 5 & . & . & 0.08 & 9 & $0.04 \%$ \\
\hline Sub-total & & & & & & & $(0.17)$ & $(5,409)$ & $(25.35 \%)$ \\
\hline Simple stock company & 0.15 & 3,681 & 0.14 & 5,639 & 0.16 & 2227 & 0.15 & 11,547 & $54.14 \%$ \\
\hline Personal stock company & 0.11 & 150 & 0.12 & 192 & 0.08 & 99 & 0.11 & 441 & $2.07 \%$ \\
\hline Stock partnership. & 0.20 & 13 & 0.35 & 6 & 0.05 & 8 & 0.19 & 27 & $0.13 \%$ \\
\hline Sub-total & & & & & & & $(0.148)$ & $(12,015)$ & $(56.34 \%)$ \\
\hline Stock company & 0.15 & 902 & 0.15 & 1,694 & 0.15 & 572 & 0.15 & 3,168 & $14.85 \%$ \\
\hline $\begin{array}{c}\text { Stock company with } \\
\text { executive board }\end{array}$ & 0.15 & 172 & 0.14 & 312 & 0.16 & 101 & 0.15 & 585 & $2.74 \%$ \\
\hline Sub-total & & & & & & & $(0.15)$ & $(3,753)$ & $(17.59 \%)$ \\
\hline Total observations & 0.16 & 8,061 & 0.15 & 9,977 & 0.15 & 3,292 & 0.15 & 21,330 & $100.00 \%$ \\
\hline
\end{tabular}

Source: Authors

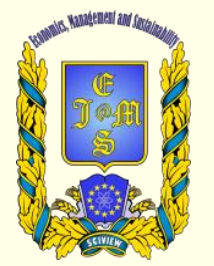

2016-2018, Economics, Management and Sustainability. All rights reserved.

This open access article is distributed under a Creative Commons Attribution (CC-BY) 4.0 license.

You are free to:

Share - copy and redistribute the material in any medium or format Adapt - remix, transform, and build upon the material for any purpose, even commercially.

The licensor cannot revoke these freedoms as long as you follow the license terms.

Under the following terms:

Attribution - You must give appropriate credit, provide a link to the license, and indicate if changes were made.

You may do so in any reasonable manner, but not in any way that suggests the licensor endorses you or your use.

No additional restrictions

You may not apply legal terms or technological measures that legally restrict others from doing anything the license permits.

Economics, Management and Sustainability (ISSN: 2520-6303) is published by Scientific Publishing House "CSR", Poland, EU and Scientific Publishing House "SciView", Poland

Publishing with JEMS ensures:

- Immediate universal access to your article on publication

- High visibility and discoverability via the JEMS website

- Rapid publication

- Guaranteed legacy preservation of your article

- Discounts and waivers for authors in developing regions

Submit your manuscript to a JEMS at http://jems.sciview.net or submit.jems@sciview.net



